\title{
Salvation in the Johannine Epistles
}

\author{
Dirk G van der Merwe \\ Department of New Testament \\ University of South Africa
}

\begin{abstract}
This article attempts to compile a soteriology in the Johannine Epistles. Circumstances and false teachings that might have influenced the theological doctrine and ethical behaviour of the community are constructed. The article argues that aspects which led to the reported schism, determine the structure and content of the soteriology. In the Johannine Epistles the "elder" teaches only basic aspects of soteriology. They are presented from theocentric and christocentric perspectives that are closely interwoven with different themes. The article demonstrates that soteriology is metaphorically presented from the perspective of the conduct of God the Father, reflecting a paternalistic Old Testament image of a household. The elder refers to three of God's characteristics: light (1:5), justice (2:29), and love (4:8). Believers have to direct their lives according to these characteristics once they have been born as children into the family of God and have experienced "eternal life."
\end{abstract}

\section{INTRODUCTION}

Soteriology, as it is dealt with in the Johannine epistles, is among the most complex (cf Edwards 2000:193) teachings in the New Testament. Nowhere in these epistles do we find a clear or categorical explanation. The soteriology is so intricately interwoven with other themes that a discussion of its various components cannot escape repetition. Like the gospel of John, 1 John has often been likened to a spiral. Throughout the epistle the author regularly returns to a point where he has been before, but by bringing in a new element he moves a step further. This spiral is not merely a technique of literary style and structure, but is equally an expression of thought-structure. ${ }^{1}$ This would imply that themes and ideas are interwoven. Therefore, it would be impossible to explore one without saying something about the others as well.

\footnotetext{
${ }^{1}$ Lieu (1997:22-23); Thomas (1998:371); cf also Malatesta (1978:77); Hiebert (1988:201); Coetzee (1993:211); Thomas (1998:371); Kenney (2000a:21).
} 
The argument to be expounded in this article will be dealt with as follows: Initially various soteriological expressions will be determined. This will help to construct the profile of the discussion. Some orientation will be provided regarding the approach to soteriology in the Johannine epistles, and the role of Jesus in the salvation events will be discussed. Special emphasis will be placed on how a person becomes saved and, finally, the implications of salvation in the lives of God's children will be expostulated.

To introduce this research, a methodological remark is necessary: Since there are close connections between the three Johannine epistles, we shall look at 1 John as the main source for this discussion of the soteriology, and 2 and 3 John will be incorporated where applicable and necessary. Any similarities or differences between these sources will be pointed out only when it is relevant and will contribute to the discussion.

\section{IDENTIFICATION OF THE VARIOUS SOTERIOLOGICAL EXPRESSIONS IN THE JOHANNINE EPISTLES}

Within scholarship two distinct and disparate views have developed concerning the message of 1 John. They have arisen as a consequence of two variant perceptions of the purpose of the epistle. The one comprises "salvation" (t $h n z$ whn t $h n$ a i jwai $n$ ) and the other "fellowship" (koinwnian) (see Derickson 1993:89-105; cf also Kenney 2000a). In fact, they are complementary to one another. Both these themes are mentioned in the prologue of 1 John, where the author (hereafter referred to as the elder) ${ }^{2}$ gives, as we may expect, a synopsis of his principal motifs.

Like the Fourth Gospel, 1 John concentrates on the assurance of the present experience of eternal life. It mentions eternal life at least 10 times, $^{3}$ always emphasising the present: $h$ mei " oi da men ot i met abebhka men ek to 'qa nat ou ei J' thn z whm (3:14). In Christ God has already given us eternal life: olek wn t on uipn ef ei thn $z$ wha (5:11-12). The purpose here is to reassure the adherents of the elder, who rejected the teaching of the

\footnotetext{
${ }^{2}$ In this chapter it has been accepted, in agreement with the point of view held by most scholars, that the three Johannine epistles were written by the same person, referred to in 2 John 1 and 3 John 1 as the pres buter o" (Brown 1997:398; Culpepper 1998:251; Kenney 2000:12). Therefore, in this document, the author will be referred to as "the elder".

3 "Eternal Life" is mentioned in 1 John in: 1:2; 2:25; 3:15; 5:11, 13, 20. The adjective a iwnio is often silently understood when $z$ wh vis used in an absolute sense: 1 John 1:2; 3:14; 5:11-12, 16 (Von Wahlde 1990:16).
} 
deceivers and abided in the teaching they had heard from the beginning $(2: 24)$, that they might know that they have eternal life $(2: 25 ; 5: 13)$.

This purpose of the epistle, according to Lieu (1997:22; cf also Thomas 1998:379; Kenney 2000a:47), is stated explicitly at the beginning (1:2), at the critical point where the opponents are mentioned for the first time (2:25f), and at the end of the letter $(5: 12 f, 20)$. Here, in the prologue, Jesus Christ is proclaimed as "the life" ( $\left.t h{ }^{\prime \prime} z w h^{\prime \prime}\right)$. He, $t h " z w h^{\prime \prime}$, has appeared and is the content of "declaration" (1:2, a pa g g ev/ omen). The excessive piling up of the four verbs a khkormen, ejwr a ka men, ejgea s a meqa and ej $h \mathrm{l}$ a f h $\mathrm{s}$ a $n$ serves but one purpose: "to stress the absolute authenticity of the evidence and thus the indubitable certainty of the faith" (Coetzee 1993:210; Strecker 1996:19).

The promise of "eternal life" at the critical point of the letter, after the initial introduction of the schismatics, constitutes both the basis for and the goal of the remaining faithful (2:25). Verse 2:23 states that denying or confessing (believe $-3: 23 ; 5: 1,5,10,13$ ) the Son is the precondition for (not) having the Father, which prepares the reader for the promise of eternal life (2:25). The same occurs in verse 5:12, where the statement "0 el wn t on uipn ef ei thn z wh $n$ " prepares the reader for the definite assurance that they shall "have eternal life" through faith in the Son of God (5:13).

What has been identified so far are the soteriological expressions from a Christocentric perspective: to believe, Son (of God) and eternal life. At the end of chapter 2 (2:29) a new perspective is introduced, but now from a theocentric point of view ${ }^{4}$, which states that a "child of God" is someone who was "born of God" and "abides in God, and God in him/her". This perspective does not oppose the Christocentric perspective, but complements it in that it describes salvation from another perspective and simultaneously links the theme of "salvation" with the theme of "fellowship". This is apparent from the fact that the Christian's conduct is demonstrated primarilly through his / her relationship with God (the Father).

In the light of the above discussion it can therefore be deduced that, Christologically, the centre of the soteriology of the Johannine epistles may be formulated as follows: "Believers can now know for certain that they have

\footnotetext{
${ }^{4}$ gegennhmeno" ek tou'qeou $(3: 9 ; 4: 7 ; 5: 1,4,18 ;$ cf $2: 29)$; t ekna qeou'(3:1, 2, 10; 5:2, 19); ek t ou 'qeou 'eśt in $(3: 10 ; 4: 2,3,4,6,7 ; 3$ John 11; cf also 2:16; 3:22; 4:21) (cf also Kenney 2000a:46).
} 
eternal life through faith in Jesus Christ, the Son of God." From a theological perspective one might say: "Believers can know that they are children of God (that they are from God) through their birth from God and consequently have fellowship with God."

A convergence of these two perspectives on the centre of soteriology is best spelled out in 5:1-5, where it forms a chiasm and proves to have the same semantic meaning.

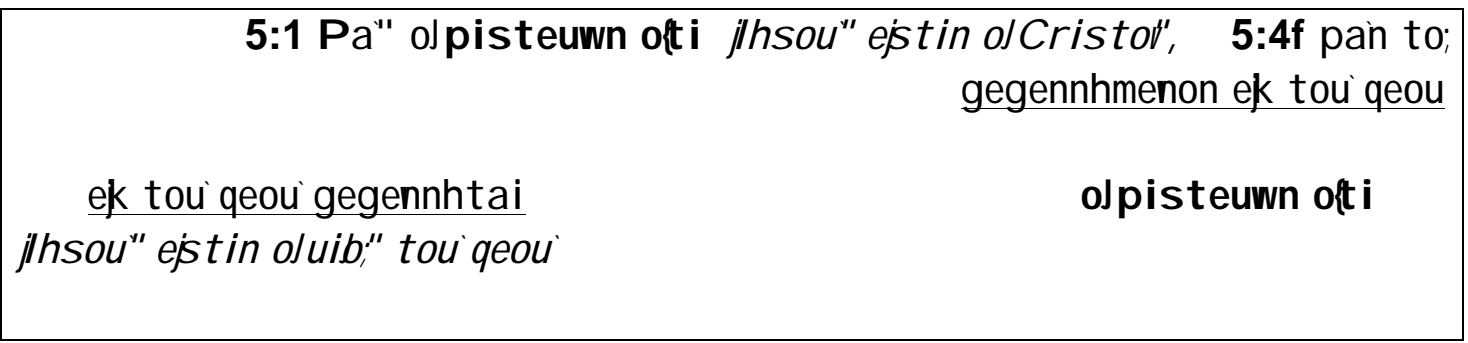

The Christological perspective focuses on the human responsibility: to believe. The theological perspective presents it from the divine side: to be born from God.

This understanding of soteriology by the elder is due to the misunderstanding of and teaching on this topic in the Johannine community, which led to a schism in the community. We will now briefly look into the social circumstances of the Johannine Community that could have caused the schism.

\section{THOUGHTS ABOUT THE SOCIAL FRAMEWORK ${ }^{7}$ THAT INFLUENCED THE INTERPRETATION AND UNDERSTANDING OF THE SOTERIOLOGY OF THE JOHANNINE EPISTLES}

First and Second John depict a community torn apart by doctrinal and ethical differences. According to Culpepper (1998:48), the differences had precipitated a schism by the time 1 John was written. In his repudiation of the

\footnotetext{
${ }^{5}$ Hengel (1989:58f) points out how the elder uses Jhs ou" C rist ol as a proper name six times, while the singular form $\mathrm{Jhs} \mathrm{ou}^{\mathrm{I}}$ is used five times in connection with confessional formulations: 2:22; 4:3, 15; 5:1, 5. See also Brown 1982:51.

${ }^{6}$ olek wn (pis t euwn) t on uipn (Jhsou" estin olCrist oly) ek ei thnzwhn ej a uf ou'gegenht ai ina tekna qeou'kl hqwimen

${ }^{7}$ When writing about the soteriology of the Johannine Epistles, one has to consider epistemological questions relating to authorship, date, purpose, central theme, and the identity of the opponents and recipients. Unfortunately there is a great deal of disagreement among scholars concerning these questions. For the purpose of this writing these questions will not be argued. I shall present the most popular and widely accepted points of view on these issues.
} 
position of the deceivers, the elder presents statements that explain his own position and that of his opponents. The statements relate to: claims regarding their status, statements about various ethical considerations and doctrinal statements about Jesus (Von Wahlde 1990:108).

These deceivers claimed a special illumination by the Spirit $(2: 20,27)$ that imparted to them the true knowledge of God. This caused them to regard themselves to be the children of God. This explains the strong emphasis by the elder on the knowledge of God and the way in which he and his adherents became children of God (to receive salvation) (5:1-5). He contrasts the heretics' claim to knowledge with the knowledge that can come only from the Christian tradition (2:24).

In response to this crisis, the elder wrote 1 John to warn the community of the dangers of this false teaching, to correct this false teaching, and to encourage those who remained faithful. II John was written to warn a sister community of the dangers that were posed by this group (Culpepper 1998:60), and III John was written to advise a certain Gaius on how to deal with Diotrephes ( $v$ 9), who was probably a schismatic (Ladd 1998:665).

From a soteriological point of view we can conclude that the dangers of this false teaching, the denial of Jesus' incarnation, would lead to an existence without God, Christ/eternal life. The correction of this false teaching would be to explain how to become children of God (have fellowship with God) and live a life in accordance with their true faith. The encouragement of the adherents of the elder would be to point out to them that they may be assured that through their faith in the Son of God (which implies obedience to his commandments) they have eternal life.

\section{ORIENTATION CONCERNING SOTERIOLOGY AS DEALT WITHIN THE JOHANNINE EPISTLES}

The angle from which the soteriology in the Johannine epistles will be approached and discussed is of crucial importance, for it contributes to the true depiction thereof. The language used to refer to the adherents of the elder is strikingly familial. These believers are tekna qeou ' $(3: 1-2,10 ; 5: 2)$, gegennhmero" ek to o 'qeou ' $(2: 29 ; 3: 9 ; 4: 7 ; 5: 1,4,18)$. They confess that God is pat hv (1:2; 2:1, 14-15, 22-24; 3:1; 2 Jn 4). These adherents are a d el $f$ on (and sisters) to each other. The elder also repeatedly addresses his flock as t ekni $(2: 1,12,28 ; 3: 7)$, and ag a pht oiv $(2: 7 ; 3: 2,21 ; 4: 1,7,11 ;$ cf 3 Jn 1, 2, 5, 11). 


\section{Salvation in the Johannine Epistles}

In his epistle the elder portrays the Christian life as existence in a family, the family of God, where God, the Father, is the head. The opponents of the elder are depicted as existing outside this family. They are referred to as tekna tou'diabovou and ek tou'kos mou eisim. In the sphere of the family the child of God will live a life true to God's nature. Already in 1:5 God is characterized by the elder as olqeo," f $w^{\prime \prime}$ ej t in kai;skot i a ej a uf w/ ouk e\$ t in oujdemi a. ${ }^{8}$ Light qualifies both God's nature and his domain (see Schnackenburg 1953:77). That God is light means that He is the origin of his family's new way of being (Malatesta 1978:105).

To become a member of this family a person has be born into it. This happens through faith in Jesus Christ, the (monogenh) Son of God. This is necessary, for the child of God has to take on the same life as the Father, which means "to walk in the light" (1:7, ej t w/f wt i; p er i p a t wimen) or, otherwise expressed "to walk just as Jesus walked". The following is a brief reference why the elder regards Jesus' role and function in the salvific events as so important.

\section{THE IMPORTANT ROLE OF JESUS IN THE SALVIFIC EVENTS}

Law (quoted by Malatesta 1978,96) remarks: “... it is the writer's immediate contemplation of the moral nature of God and his governing idea of salvation as participation in that nature that inevitably cause him to carry up the thought of the indwelling Christ to the ultimate truth of the indwelling God." Hence, God's own life has been revealed to us in Christ. It is because God is pure light and without any darkness that he can purify his children through Christ, enabling them to walk in light and to have fraternal communion (cf 2 Cor 5:14). Through Jesus Christ a person receives God's light and life because he himself, the Son of God, is the light and life (1 Jn 1f; Jn 1-4).

This is the case because a unique relationship exists between the Father and his Son Jesus Christ. Throughout 1 and 2 John Jesus is mentioned in association with the Father, predominantly with the connotation "the Father of Jesus Christ". ${ }^{9}$ In these letters this title reflects the intimate, indissoluble unity between the Father and the Son (Coetzee 1993:219). One

\footnotetext{
${ }^{8} \mathrm{God}$ is also characterized elsewhere in 1 John as: "p i s t o "ağph" (4:16).

${ }^{9} 1: 2,3 ; 2: 1,22-24 ; 4: 14 ; 2$ John 3, 9; cf also 1:2; 4:2, 3, 10; 5:10.
} 
gets the impression that in his total opposition to the false prophets (y eudop r of ht a i, 4:1) the elder wishes to emphasize the intimate bond of love between the Father and Son and their essential unity.

When Jesus is referred to as to ou 'ui bu'a uf ou' or (monog enh', 4:9) t on uipn, it is in close conjunction with "the Father" (0)pat hr): "P a " 0 f ajnoumeno" ton uipn oude;t on pat eva ek ei, olomol ogwn t on uipn kai; t on pat erra ek ei" (2:23; see also $1: 3 ; 4: 14)$. A repeated parallelism occurs, effectively putting the Father and the Son on an equal level (1:3; 2:23; $4: 15 ; 5: 11,12)$ (Edwards 2000:160). The close bond between Jesus as Son and God as Father is such that for the believer the experience of one carries with it experience of the other (2:24) (Lieu 1997:72).

- $\quad$ For the Father to communicate his "light" ( $f$ wt $i$ ) to the world the Son of God had to become incarnate (cf 2:6; 3:5, 16; 4:2).

- The incarnation was the outcome of the sending of God's only Son into the world so that God's children might live through him (1 Jn 3:16; $4: 9,10,14)$.

- The Son of God has come and has given us understanding so that we may know Him (God) who is true (5:20, 21; cf further 2:13-14; 3:1; 4:6-8).

- The life that God has given to his children is in his Son. This life originally "existed with the Father" (1:2); and it is perfectly manifested in God's Son (cf 5:11b). The term "life" is a soteriological term, which the elder explains as $t h \grave{n} z$ whn $t h n$ a ijwaio $n^{10}$ and which indicates the quality of life (cf Derickson 1993:97; Hiebert 1988:206) in God's family, which God has made available through the earthly ministry of Jesus (5:6; cf 1:1-2; cf Jn 3:16; 17:2-3).

- $\quad$ Another reason why the Son of God was revealed (ef a ner wqh) was ina I ush/t a; elga tou'diabolvou (3:8).

- $\quad$ The Father's saving act culminated in Jesus' death. The elder argues repeatedly that $\sin$ is forgiven through the expiatory sacrifice of Jesus $(1: 7 ; 2: 2,12 ; 3: 5,16 ; 4: 10)$.

- In 2:1 the elder deals positively with the problem of sin: if anyone should sin, God has made provision for this - parakl ht on ef omen pro," t on pat eva, Jesus Christ. But Christ is also called dika io" in

\footnotetext{
${ }^{10}$ For this concept see John 17:2-3; also John 3:15-16; 5:24-26; 6:40, 47, 68; 10:10, 28; 11:25-26. The aorist tense of the verb edwken emphasizes the factual and historical background to God's saving activity.
} 
2:1. This predicate ("being righteous") heightens the description of his ability to act as the sinner's intercessor.

- One of the reasons why Jesus could abolish sin was because in him there was no $\sin (3: 5)$. This description of Jesus as sinless (cf also 1 Pt 1:19, 22; 3:18; Heb 8:26) is matched by the elder's positive assertions that Christ was dika i o $\mathrm{f}(2: 1,29 ; 3: 7)$, a g i $\boldsymbol{0} \sim(2: 20)$ and agno"v (3:3).

It has been indicated that the elder's depiction of Jesus was intended to prove to his adherents that Jesus is the Christ (who came with a decisive mission of salvation) and the Son of God (who incarnated in Jesus). Therefore, he is the light and life for mankind. Only through faith in him can people become children of God.

\section{RECEPTION OF SALVATION}

If God's Son is the Saviour, how then do people become children of God? To answer this question the elder guides us. Sinners live in darkness and consequently cannot enjoy fellowship with God $(1,6)$, who is light $(1: 5)$. In order to become saved a sinner has to be born into the family of God. This realizes through faith in Jesus Christ, his Son. Before discussing these aspects of salvation we shall first have to look briefly into the elder's epistemology about sin. Sin keeps those who are ek to o 'k os mou captured in darkness from where they have to be freed, while it influences negatively the fellowship of the tekna qeou! 'It is clear that the author regards sin with the greatest abhorrence, seeing it as incompatible with God's character and with the status of believers as God's children" (Edwards 2000:193).

\subsection{An orientation about the elder's perspective on sin}

The claim to have "fellowship" (ko inwni a ) with God the Father is a lie when it is combined with a wandering in darkness (1:6). For the elder, walking in the light is grounded in the fact that God's divine nature is light (Strecker 1996:28). To "walk in the light" is to have fellowship with God (1:6) and with one another (1:7), which relates to "love for one another" (2:10). In 1 Jn 2:11 the elder points out that ej $t$ w/s kot ei peripat wmen refers to mi s wh t on a del $f$ on a uf ou' In 3:14 and 15 the elder substitutes this phrase with qanatrou (v 14) and ouk ek ei zwhn a ijwnion (v 15). Therefore, ej t w/ s kotei peripat wmen would mean: "abiding in death" (3:14), "do not have eternal life abiding in that person" $(3: 14,15)$ (Strecker 1996:29; Baylis 
1992:215; see Perkins 1983:631-641 for a discussion on k o inwnit in relation to "walking in light/darkness").

In 1:8 and 10 the elder tries to explain the position of the believer with regard to sin, where he states that no child of God can say a ma r t i a n ouk el omen. ${ }^{11}$ Perfection cannot be attained until God's children become like Jesus at his parousia (3:2). But the elder was also concerned that his opposition to sinless perfection could lead to misunderstandings among God's children, therefore he added: "t a ut a grafi w umi ǹ i k a mh; a ma wt ht e" $(2: 1)$. What the elder is saying here is that $t a$; $t$ ekna t o u 'qeou'also sin ( $1 \mathrm{Jn}$ 1:8-10). In 1:9 and 5:17 he refers to this sin as a di ki a " (NIV, "wrongdoing") and clarifies it in 5:17 as a mart i a oujp ro," qa mat on.

Vitrano (1987:129) purports that it can be assumed that the mind of the elder here goes back to what he has expressed in 2:1-2. From these two verses it seems apparent that because t a; t ekna to ' 'qeou'have a parakl ht $0 \sim$, their sin is not pro," qa mat on. In the absence of such a parakl ht $0 \sim$, there is no hope. While Christ is the if a s mov (2:2) for the sins of the whole world, he is the parakl ht $0 \sim$ only for those who believe that he is the Christ (5:1), the Son of God (5:5).

But the children of God ought to acknowledge ${ }^{12}$ their sins ${ }^{13}$, and if they do, God responds (1:9). The acknowledgement of sin brings into focus the two separate qualities in God's character (1:9): his faithfulness and his righteousness (pis t o" ejs in kai; dikai o"). God's saving action, in response to acknowledged sin, operates in two directions: forgiveness of sin and purification from "every kind of unrighteousness" (Smalley 1984:32). However, those ek t ou'kos mou $(2: 16 ; 4: 5$; also called t ekna t ou' diabovou) are without a parakl ht $0 \sim$, consequently is their sin a mart i a

\footnotetext{
${ }^{11}$ This the elder explains in 1 John 1:5-2:2 round a series of six conditional sentences. Each one concerns the place of sin in the life of the believer (see Baylis 1992:220ff; Culpepper 1998:256f ; Kim 1998:121f; and Kenney 2000a:20 for a discussion on this). Similar patterns are to be found in 1:7, 9 and 2:1-2.

${ }^{12}$ Westcott (1982:23) may be right when he suggests that an element of public confession before others, as well as God, is involved, for elsewhere in the Johannine corpus the verb omol ogein is used in the sense of open "witness" (see 2:23; Jn 1:20; Rv 3:5; cf also Mt 10:32; $\mathrm{Rm}$ 10:9).

${ }^{13}$ Bultmann (1978:21) refers to the fact that the confession of sin, as well as having fellowship with other Christians, belong together with walking in the light and characterizes the Christian's existence.
} 
pro," qa mat on ${ }^{14}$ and has to be interpreted in the context of the epistle as a whole (cf Vitrano 1987:129) and relates to "lawlessness" (3:4, a jo mi a). ${ }^{15}$

In 3:8 it seems as if the elder contradicts what he wrote previously about sin in the lives of God's children: "0 p oi wh t hn a mart i an ek t ou' diabovou eśt in" and "P a" olgegennhmemo" ek tou'qeou'amartian oujpoiei, oti i sperma a ut ou ej a ut w/menei, kai;oujdumat a i a mart a mein, oł i ek tou'qeou'gegemnht a i” (3:9).

This is certainly no contradiction. The point the elder wants to make is that a person who is born of God cannot continue to live in sin because a new principle of life has been implanted in that person (Strecker 1996:100). There must be an obvious change in the person's conduct. When a child of God

\footnotetext{
${ }^{14}$ By using reciprocals the elder effectively and dynamically describes sin in relation to its counterpart, salvation. The following is a list of reciprocals that occur in al three the Johannine epistles:
}

\begin{tabular}{|c|c|c|}
\hline Texts & s wt hrig side & a martig side \\
\hline a) $1: 6 f$ & a) ej t w/f wt i;peripat wimen & a) ej tw/skotei peripat wimen \\
\hline b) $2: 3,4$ & b) ta," ejt ol a," a uf ou'thrwimen & b) t a," ent ol a," a uf ou 'mh;t hr wǹ \\
\hline c) $1 \mathrm{Jn}$ & c) olagap wn t on adel fon a ut ou en & c) oll egwn ej t w/f wt $i$;eihai kai;ton \\
\hline $2: 9 f$ & t w/f wt i;menei & $\begin{array}{l}\text { a plel f on a ut ou 'mis wh en th/s kotia/ } \\
\text { est in ev" a t i }\end{array}$ \\
\hline d) $2: 21 \mathrm{ff}$ & $\begin{array}{l}\text { d) al hqei a" ... olofmol ogwǹ ton uipn } \\
\text { kai;ton pat era efei }\end{array}$ & $\begin{array}{l}\text { d) y eudo" ...pa" ojajnoumeno" ton uipn } \\
\text { oude; on pat era é ei }\end{array}$ \\
\hline e) $4: 2-5$ & $\begin{array}{l}\text { e) pañ p neuma o \}omol ogei ... umei" } \\
\text { ek t ou qeou 'és te }\end{array}$ & $\begin{array}{l}\text { e) paǹ p neuma o\}mh;omologei ... a uf oi; ek } \\
\text { tou'kos mou eisin }\end{array}$ \\
\hline f) $4: 6$ & f) pneuma t $h^{\prime \prime}$ a f hqeia" & f) pneuma th" $p \mid a m h "$ \\
\hline $\begin{array}{l}\text { g) } 4: 12 \\
20 \\
\text { h) } 5: 12\end{array}$ & $\begin{array}{l}\text { g) eán agapwimen al I hwou" } \\
\text { h) ojekwn ton uign ek ei thn zwha }\end{array}$ & $\begin{array}{l}\text { g) ol mh; ag a pwn ton a del f on a ut ou } \\
\text { (mish) } \\
\text { h) ol mh; el wn ton uipn tou'qeou't hn zwhn } \\
\text { ouk elcei }\end{array}$ \\
\hline & & $\cdots$ \\
\hline i) $2 \operatorname{Jn} 9$ & $\begin{array}{l}\text { i) olmenwn ej th/didachl out o" kai; } \\
\text { ton pat era kai;t on uipn ef ei }\end{array}$ & $\begin{array}{l}\text { i) pa" olproagwn kai;mh;meawn ej th/ } \\
\text { didach/tou'C ristou'qeon ouk ek ei }\end{array}$ \\
\hline i) $3 \mathrm{Jn} 1$ & j) (mi mou) to; aga qon... & -2 \\
\hline k) $3 \mathrm{Jn} 11$ & k) olaga qop oi wǹ ek tou'qeou'ess t in & j) mh;mi mou 't 0 ;kakon ... \\
\hline & & K) os kakopoiwn ous eysiaken con qeom \\
\hline
\end{tabular}

These reciprocals echo the character of apostacy. This variety of perspectives relates to the doctrinal and ethical problems the Johannine community experienced due to the y eudop r of $h t$ a . These formulas are used in order to define sin on doctrinal level as the denial of the Incarnation (1 John 2:23; 5:12; 2 John 7, 9), and on an ethical level to do evil (3 John 11 ), to hate brothers (and sisters) $(2: 11 ; 4: 20)$ and not to obey God's commandments. These formulas also point out the seriousness of being guilty of these kind of sins because the consequences are to be denied having eternal life / fellowship with God and Christ (ouk ek ei t on pat era kai;t on uipn). This category of sin can be depicted as a martia pro," qa mat on and excludes people from kinship in God's family.

${ }^{15}$ See Brown (1982:399f) and Hills (1998:286-299) for a thorough discussion on ajnomiva. "Lawlessness" can be defined from the immediate context as t a; ef ga t ou'diabovou (3:8). The people who commit this sin are referred to as t a; tekna t ou'diabolvou $(3: 8,10)$. 
follows Christ, (s)he will break with his / her sinful past (see 1 Jn 2:29; 3:3, 7, 10; Mt 7:18; Rm 6:7, 12) ${ }^{16}$ ( Ladd 1998:663; cf Von Wahlde 1990:167ff for a thorough discussion). ${ }^{17}$ According to the New Testament, being children of God certainly makes a difference in people's attitude towards acts of obedience versus acts of disobedience. It involves a reorientation - an orientation towards God and an orientation away from Satan and the world. The actions that result from that orientation must be interpreted and evaluated in the light of that (re)orientation. ${ }^{18}$ In situations where sin has been committed ignorantly or unwittingly, the elder encourages intercessory prayer (5:16) (Vitrano 1987:130).

It is evident that the elder clearly distinguished between sin inside and outside God's family: sin inside the family no longer leads to death for sinners because they have the only Son of God as their paraclete. Those still outside the family have no advocacy, therefore their sin is sin unto death.

\subsection{Faith as a means to obtain salvation ${ }^{19}$}

It is only through faith that people can receive God's light and be born into the family of God. In 3:23 the elder gives a double command. The one objective in this command is to believe in Jesus as Christ $(2: 22 ; 5: 1)$, as Son $(2: 23)$, as $d$ to as ex a uf ou (qeou) gegemnht a i (2:29). 1 John, like the Gospel (Jn 3:3), speaks of entry into the family of God as a new birth, being begotten by God, having the seed of God implanted in his child's inner being (2:29; 3:9; 4:7; 5:1, $4,18)$. Here the elder uses language commonly used when speaking of family life to express Christian truths.

\footnotetext{
${ }^{16}$ Malatesta (1978:246) points out that if for the elder sin means a refusal to accept the revelation of love, which Jesus is, and therefore the refusal to love Jesus, the Father, who sent him, and the brothers for whom he came, then not sinning means loving devotion to the person of Jesus. Right relationships with the Father and with our brothers and sisters derive from a right relationship with Jesus.
}

${ }^{17}$ Porter (1997:1098) states that in the argument of the letter the reality is stated before the ideal. The reality is stated in 1:8-10 and the ideal in 3:6 and 5:18.
${ }^{18}$ The above point of view of a particular orientation to sin is not peculiar to $1 \mathrm{John}$. It is a basic Christian doctrine which occurs throughout the NT. See Rom 6 and 8 where Paul's doctrine of $\sin$ and salvation is underlined.

\footnotetext{
${ }^{19}$ Not much is said about faith in these epistles. The elder uses the verb $p$ is t euw nine times (3:23; 4:1, 16; 5:1, 5, 10, 13) and the noun pigt i " only once (5:4) (Filson 1969:274 refers to ten). All these texts occur only in 1 John. The event word p is t euw is often implied in the elder's frequent references to ek ein, merein and omol og ein. This is due to the fact that he is writing to those in the community who are children of God and abide in what they have heard from the beginning. Then there is also the implication of "false belief" from the side of the yeudoprof ht ai (planwat wn).
} 
In 2:29 the elder probably preferred to use the phrase ej aut ou ${ }^{20}$ gegernht a i by way of introduction to the sebsequent section where the theme t ekna qeou is introduced. Another way of expressing the same truth is to speak of pis t euwn ei f' t on uipn tou'qeou'(5:10), ol ek wn t on uipn (5:12), even as the Gospel (1:12) speaks of e[ a bon a uf on (Jesus). In this context it seems as if the expression ex a uf ou'g egemnht a $i$ in 2:29 expresses a close and intimate relationship that relates to "we walk in the light" (ej t w/f wt i; peripat wmen, 1:7). Used metaphorically, the verb genna w serves to indicate a relationship that is comparable to a family relationship, i.e. that between a father and his child. Through their rebirth God's children enter into a new relationship; they become his children (3:1, 2, 10; 5:2). Paul sees believers as children of God, but by adoption rather than by new birth (Rom 8:15). However, in the new birth and the implanting of the divine seed, the elder clearly sees something more than a new relationship. It means, according to Ladd (1998:664) that a new dynamic, a new power, has entered the human personality, which is confirmed by a change of conduct. A child of God has found a new orientation of his will - to do the will of God, to love and obey Him, to break with sin and to follow the path of righteousness.

In 2:29 the phrase ej a uf ou'gegennht ai is linked with poi wh thn di ka i os unhn. "To do right", or "to do what is right", is used here (and in 3:7, 10) in the sense of imitating Christ, who did what is right. This can also be compared with "walking in the light". Dikaios unhn is what is in accordance with the will of God. Thus pa" ofpoi wni thn dikaios umhn is the proof that ej a uf ou'gegernht ai (2:29).

The same thought is expressed negatively in 3:9 and 5:18: "P a " 0 f gegennhmeno" ek tou 'qeou'amart ian oujpoiei", and positively in 5:4, where the consequence mentioned is ni ka/t on kos mon. In other passages (cf $2: 29 ; 4: 7 ; 5: 1$ ) the child's behaviour is viewed not as the consequence, but as the proof of his/her being born of God.

Another expression which closely relates to the phrase ej a uf ou gegennht a $i$ is the phrase oki sperma a uf ou'ej a uf. w/menei (3:9). This phrase can best be interpreted metaphorically as a reference to the source of life, which God implants in his child (Haas, De Jonge and Swellengrebel

\footnotetext{
${ }^{20}$ In all the other occurrences $(3: 9 ; 4: 7 ; 5: 1,4,18)$ the pronoun a ut ot is substituted by qeo $\forall$. According to Haas, De Jonge and Swellengrebel (1972:75) the pronoun here refers to God, as is clear from the next verse.
} 
1972:84). Thus the point in 3:9 may be that God's seed is to be found in those He has chosen (eklekt hl 2 Jn 1), who have been born of Him (Lieu 1997:35).

Not only are believers born of God and consequently called children of God; they are also referred to as ek t ou 'qeou'. Strecker (1996:83) relates these three expressions as follow: "If the 'children of God' are born of God, they are 'from God' (ek t ou 'qeou)." These images are used in close relation to one another in 3:10 and 5:18-19. From these two texts it is clear that more than belonging to or coming from God is meant; the phrase ek tou 'qeou, ${ }^{21}$ in relation to these other two phrases (ek t ou'qeou'gegemnht ai and t ekna qeo $\mathrm{u}^{22}$ ), points to a divine origin. It is furthermore used as a strong affirmation - the adherents of the elder are of God $(4: 4,6 ; 5: 19) .{ }^{23}$

\subsection{Life as an existence in the family of God}

Life in this new family is expressed as "eternal life". The agonizing scene at the cross described in the Fourth Gospel, where Jesus entrusts his mother and "the disciple whom he loved" to each other, establishes the new family. Whereas the familial imagery had once referred to the family created by Jesus' call, as opposed to the natural family of Judaism, the imagery is now used to refer to those who remained faithful to the message that had been passed down from the beginning of the family's existence (Achtemeier, Green, Thompson 2001:546f).

In the symbolic narrative of 1 John, group orientation (koinwnita) constitutes the socio-structural core. ${ }^{24}$ Here the pattern of the patriarchal family exists. The existence of obedient members is totally determined by their group adherence. If such group adherence and its corollaries are negated, the respective narrative structures will collapse. In 3:11-18 the anti-group

\footnotetext{
${ }^{21}$ In John 8 Jesus' opponents do not listen to his word, which is the word of God, and consequently prove themselves to be not "of God", but of their father the devil.

${ }^{22}$ When the elder addresses his readers as "children" he uses different words - $t$ ekni ( $2: 1$, $12,28 ; 3: 7,18 ; 4: 4 ; 5: 21)$ and pa idi a $(2: 14,18)$. In contrast 2 and 3 John use only tekna (2 John 1, 4, 13; 3 John 4) for the community.

${ }^{23}$ This concept is more explicitly defined in chapter 3 . Still under the influence of the story of Cain (3:12), "not to be of God" is reciprocally formulated as "to be of the devil" (3:8) or "of the evil one" (3:12). There are spirits that are of God and others that are not. The spirits not of God are tou'ajt icrigt ou (4:3) or t 0; p neuma t $h$ " planh" (4:6). The parallelism here suggests a real symmetry between being of God and being of the devil (Lieu 1997:39).

${ }^{24}$ I support Van der Watt's (1999:148ff) point of view with regard to this new life in the family of God.
} 


\section{Salvation in the Johannine Epistles}

behaviour of a deceitful brother (Cain) is explained and denounced. This behaviour shows that such a person does not belong to the family, since members of a family care for one another (3:16f) and will certainly not harm one another. Family cohesiveness and corresponding loyalty will be manifested through "right" behaviour towards one another (3:10). In 1:6-2:2 the elder describes the problem of violating the conventions of such a family (group). If such a wrongdoer (a hnart i a ) still claims to be a member of that particular family, confession is required (1:9), so that the relations within the family can be restored. The Father deals with such matters in cooperation with the parakl ht $0 \sim$, who acts on behalf of the family (2:1-2).

1 John 1:3-4 describes how a person is invited into koinwni a with other members of the family (meq jh hnwn') and the Father and his monog enh '(4:9) Son. This is a spiritual family that supercedes, existentially and ethically, the physical family to which a person belongs. According to the elder a person lives spiritually while that person is still on earth. This implies that that person exists in a different mode of being on earth - already possessing eternal life. This implies membership of another (spiritual) family. Supreme loyalty is owed to this spiritual family. To become part of such a family, a person needs to be born (g enna $n-2: 29 ; 3: 9 ; 4: 7 ; 5: 1,4,18)$ into that family. Then new birth into a new family will reorientate the person's thinking and conduct. Living according to the demands of this new family implies that the member must accept that (s)he certainly is a member of this new family. By accepting this new way of life, new rules and new values replace previous traditions, rules and values. This is what conversion comprises.

A question that arises is how this new existence can be experienced in a concrete way. God now lives with and in his children by way of the Spirit (3:24). The Holy Spirit is the one who applies to God's children the redemptive work of the Father and the Son (2:20). The Spirit witnesses to this truth (5:6a). The chief functions of the Spirit are those of illuminator (2:20), teacher (2:27), empowerer (3:24 in the context of obedience; $4: 13$, in the context of love $)^{25}$, confessor (4:2) and witness (5:7f) (cf Kenney 2000a:47). The Spirit becomes the guiding influence in the lives of God's children $(2,20-7 ; 5: 7)$, influencing their conduct. It is the Spirit that influences and leads these children to act right (di ka i o V - 2:29; 3:7, 12; cf also 3:10), to walk just as Jesus walked (2:6). The Father takes care of his family through his Spirit. One should be

\footnotetext{
${ }^{25}$ Kenney (2000a:47) points out that 1 John awards equal importance to the three themes of obedience $(1: 5-2: 6 ; 2: 29-3 ; 10 ; 5: 13-21)$, love (2:7-11; 3;11-18; 4:7-21), and belief (2:18-28; $4: 1-3 ; 5: 5-12)$.
} 
cautious not to confuse all spiritual experiences as coming from the Spirit of God (4:1-2). The Spirit will give God's children knowledge (0 i da t e - 2:20). Only God's Spirit will guide the believer in the truth (5:6) (see also Von Wahlde 1990:126ff).

When people are born into the family of God, they should not only be what they are born to be, but should also live according to the tradition of their new family. The elder emphasizes the important role of the tradition in 1:1-4 (cf also $2: 24 ; 5: 20$ ). The children of God should follow this "Jesus tradition" in their daily life. Jesus' conduct and actions were inspired by God, who is described as love (4:16). This is why the life of a member of the family of God should be characterized by love $(4: 7-8 ; 3: 16)$.

\section{OUTCOMES OF SALVATION}

When people became part of God's family, as a result of their birth from God, major changes occurred in their lives. The picture of these children of God, concerning their change, is derived from analyses of status, and change in their social behaviour. In each of the three documents the picture of these children (adherents of elder) is clearly contrasted with a similarly developed picture of those "ek t ou 'kos mou" (opponents of elder). Each epistle demonstrates the intent to persuade the reader/hearer to either become or to remain part of God's family (cf Kenney 2000:117f).

\subsection{Salvation described as a change of status}

The status of the adherents of the elder as t ekna qeou is emphasized in all three epistles ( $1 \mathrm{Jn} 3: 2 ; 2 \mathrm{Jn} 1 ; 3 \mathrm{Jn} 4$ ), but in each some tension is evident between the portrayal of God's children as individuals, related to God independently through personal faith, and the corporate dimension of this relationship to God. 1 John underlines the autonomy of the individual child of God $(2: 20,27 ; 5: 20)$, but qualifies this emphasis with the thematic development of the concept of fellowship with brothers (koinwnit in 1:3; 4:6). This tension is recognized in 2 John 1, 7, 9 and 11, while references to individuals as members of God's family occur in vv 1-6, 8, 10, 12 and 13. 3 John is the only Johannine letter that is clearly addressed to an individual (Ladd 1998:665). Yet the tension of the child of God's individual apprehension of truth versus its corporate realization is apparent. This is clear from the elder's alteration between references to Gaius as an individual ( $v v 1,2,5,6$, $11,12,13)$ and those that bind him to a family of God's children (vv 3-8, 12, 14).

Election (ekl ekt $h \bar{\gamma}$ is emphasized only in 2 John 1 . Only 3 John 14 refers to God's children as friends ( $f$ i voi ). 1 John 3:2 and 3 John 1 address 
God's children as beloved (a g a p ht W). Kenney (2000:117) also pointed out that privileges attend the children of God in each of the epistles, though not necessarily the same privileges. For example, knowledge of God is emphasized only in 1 and 2 John. 2 John 8 is unique in its mentioning of reward (mi s 90 $\sim$ ) for God's children, and it is only in 3 John 8 that God's children are referred to as co-workers (s uner $\mathrm{g} 0 \mathrm{i}$ ) in the truth. 1 John 5:20 emphasises the privilege of understanding (di a no i a $n$ ).

\subsection{Salvation described as a change in social behavior}

The obligations of the children of God in the family are spelled out in all three Johannine epistles and in each case contribute to an understanding of the behaviour of these children, which is associated with walking. 1 John 1:6 speaks of the right conduct as walking in the light, whereas 2 John 6 specifies the commandments as the sphere of walking, and 3 John 3 identifies truth as the sphere of behaviour (Kenney 2000:117).

The behaviour of God's children has to relate to the social behavior (rules and values) of the family into which they are born. "Family life" implies specific ethical conduct. Therefore the elder insists upon a correspondence between internal state and external behavior. The a $\mathrm{g} g \mathrm{el} i \mathrm{i}$ correlates to ejt $\mathrm{ol} h$; Gospel and commandment are but two aspects of a single revelation given in Christ (Kenney 2000b:21). The rules of conduct are determined by the head of that family. ${ }^{26}$ This conduct has to be imitated (2:6) and followed (2:17).

The highest claim believers can make for their lives is to claim fellowship with God, which implies that they have come to know the character of God (Jn 17:3) and that the character of God has become the transforming reality in their lives. In 1 John three definite statements are made about God's character: "0Jqeo", f w" es t in" (1:5), "[0|qeof"] dika iov ej t in" (2:29) and "0)qeo;" ag gaph eśt in" (4:8) (cf Malatesta 1978:xvff; Culpepper 1998:269). The following is a brief description of the conduct of God's children as a result of their kinship. ${ }^{27}$

\footnotetext{
${ }^{26}$ As theology dominates the Fourth Gospel (see Thompson 2001:1ff), is 1 John also the ocentric (cf Lieu 1986:198; cf also Malatesta 1978:96): it explores the nature of God's character.

${ }^{27}$ Compare Malatesta 1978, Von Wahlde 1990, Culpepper 1998, Kim 1998 and Kenney 2000a, who basically use the same structural division.
} 


\subsubsection{A community faithful to the confession: God is Light}

In 1:5 the elder declares that olqeo," $f w^{\text {" }}$ es t in kai;s kot i ej aut w/ouk es t in oujlemi a. Culpepper (1998:257; see Malatesta [1978:96ff] for a thorough discussion on light) pointed out that light is universally regarded as a quality of the divine character and that the holiness or goodness of God is intended. Those who would have fellowship with God (1:5-2:11) must therefore have nothing to do with skotia, which includes everything that is at enmity with God (Danker 2000:932; cf Edwards 2000:165). Several tests are pointed out and discussed by the elder with regard to having fellowship with God:

The first test for having fellowship with God - The danger of denying sin: The assumption drawn from the assertion that God is light was that, since there is no darkness in God, there can be no darkness in his children. God's children cannot live in fellowship with their Father if their lives are darkened by sin. Moreover, they cannot deny the reality of sin, even among themselves, but have to confess their transgressions $(1: 8,9 ; 2: 1,2)$ when they do $\sin (1: 7$, 9; 2:2) (cf Von Wahlde 1990:216; Kenney 2000:21).

The second test for having fellowship with God - Obey His command: The elder says that to truly know God, his children must keep his commandments. In this pericope (2:3-10) three central affirmations occur: "eg nwka men a uf on" (2:3a), "ej a ut w/memein" (2:6a), "ej t w/f wt i; eihai" $(2: 9 a)$. The tests attached to these affirmations, $t a$," ejt ol $a$," a uf ou ' thr wmen (2:3b), a uf 0," "ouţ w" 1/4p eripat eiǹ (2:6c), a g a p wh̀ t on a del $f$ on a ut ou (2:10a), have to be understood as a progressive unfolding of the underlying truth in God's children. These ethical exhortations, proceeding from the context of Jesus as the means of fellowship (1:6-2:2), culminate in the necessity (of ei vei ) of imitation (ka qw", ekeinno") of Christ (Kenney 2000a:22; cf also Von Wahlde 1990:217). ${ }^{28}$

The third test for having fellowship with God - Love for the Father versus love for the world: In 2:12-14 the elder proclaims the blessings of the gospel. In each affirmation there seems to be an implicit command; calling God's children to be (imperative) what they are (indicative). If forgiveness (af ewnt a i) of sins, knowing (eg nwka t e) God, the abiding (memei) of God's

\footnotetext{
${ }^{28}$ In 2:7-11 the elder discusses his exhortation to keep God's commandments $(2: 3,4)$. The one who fails to love his brother, abides in the darkness, walks in darkness, does not know where he is going and is blind. This is the opposite of knowing the Father (Kenney 2000a:22). Kenney (2000a:23) points out that in these first two units the focus is on Jesus as the model of holy living. Here we find a theology of Jesus as the expiatory means (1:5-2:2) and an exemplary model (2:3-11).
} 
word in them, and victory (nenikhkat e) over evil are ascribed to these children, they should act in accordance with these qualities. Therefore 2:15-17 could be best explained, according to Johannine dualism, as an admonition not to backslide into the sphere of the world (Von Wahlde 1990:217; Kenney 2000a:24f). Therefore the elder invites God's children to walk (p er i p a t ei in) as Jesus walked (2:6), for Jesus did the will of God who sent him (Jn 4:34; 6:38) (Brown 1982:327).

The fourth test for having fellowship with God-Combat the heresy among you: To combat heresy the elder reminds God's children of two aids, namely the Spirit and the Word. The children of God received a c $r$ is ma (2:20), which is probably an assurance that they have been anointed by the Spirit. The elder exhorts these children to hold fast to (mei ahy o fh kous a t e a p jaj ch" (which refers to the "word") (Von Wahlde 1990:217f). Only the Spirit will guide the children of God to know the truth ${ }^{29}$ (Culpepper 1998:262).

\subsubsection{A community faithful to the confession: God is Righteous}

In 2:29 God is depicted as dikaiov ej t in. The appeal by the elder poiein thn dika ios unhn leads to a clear distinction between t ekna qeou'and t ekna t ou'dia bovou. Consequently he provides the children of God with a few benchmarks or standards poi ein thn dikaios unhn:

The First Benchmark of Doing Right: Avoid sin. The elder has recognized the continuing presence of $\sin$ in the lives of these children, as well as the danger of assuming that a child of God no longer needs to be concerned about sin. They are reminded that those who abide in Christ and have the Spirit abiding in them will lead lives characterized by righteousness (2:29), rather than by $\sin$ (Culpepper 1998:263ff) and a g ni g ei ela ut on, kaqw", ekeiǹo" agnov" eśt in (3:3) (cf Von Wahlde 1990:218).

The Second Benchmark of Doing Right: Love one another. ${ }^{30}$ The elder emphasizes the importance of exemplary love among God's children within the Christian community. Those who know Christ and practise love met a bebhkamen ek tou'qa natou ei J' thn zwha (Culpepper 1998:170).

\footnotetext{
${ }^{29}$ The truth (a) hqei a ) concept is also present in each of the Johannine epistles, but the adherents' obligation with regard to the truth is portrayed in various ways: 1 John uses the language of believing, whereas 2 and 3 John simply utilize the metaphor of walking in the truth.

${ }^{30}$ Verses 13-18 refer to the specific requirements of the love command. Verses 19-22 give the assurance that the believers who live by God's commandments need not to fear God's judgment. Verses $23 f$ conclude the section by confirming that those who obey his double command of "faith in his Son Jesus Christ and love for one another" will abide in God.
} 
They can be assured that they abide in God and God abides in them (cf Thomas 1998:374). This leads the elder to refer to the example of Jesus' sacrificial love (3:16).

The Third Benchmark of Doing Right: The testing of spirits. In 1 John 4:1-6 the elder encourages the community to test the spirits because there are many false voices. Two criteria are mentioned here for distinguishing the true prophets from the false ones: the content of their message (0 mol og ei ' J hs oun Crist on en sarki;el hl uqota) and their reception by the world (Von Wahlde 1990:219; see Hiebert [1989a:420-436] for a detailed discussion).

\subsubsection{A community faithful to the confession: God is Love}

Love comes from God and is rooted in faith: ${ }^{31}$ All who practise love for others show that they have come to know something about the character and nature of God. They are living in response to God's love as His children. Jesus is not only our example, but is the one who, by his example, brings the ability (gegemnht a i - 4:7) to imitate him (Kenney 2000a:32). In verses 4:13-16a the elder points out that faith in Jesus is the response to God's love which enables the community to practise love for one another (Culpepper 1998:270; also Kenney 2000a:33).

Faith in the Son of God is the root of love: The elder states (5:1-4) ${ }^{32}$ that believing is related to the imperative of love. The person who lives in fellowship with God will inevitably love others who share in this fellowship. Confessions of love for God can be true only when they are accompanied by obedience to God's commands.

\section{CONCLUSION}

The Johannine Epistles provide no elaborated account of salvation. In this article an attempt was made to compile a comprehensible soteriology in which

\footnotetext{
${ }^{31}$ Scholer (1990:309) refers to p is t euw and ag a p h as the two criteria by which true membership in the Johannine community is determined: a) believing in the name of Jesus Christ who is the Son of $\operatorname{God}(3: 23 ; 5: 1,5,10,13)$ or confessing that Jesus is the Christ, the Son of God (2:22-23; 4:2-3, 15); and b) loving one another (3:11, 23; 4:7, 11-12, 20-21). These two criteria are brought together in 3:23-24.

${ }^{32}$ Previously discussed themes are brought together (Culpepper 1998:271; Edwards 2000:171): belief in Christ and obedience to the love command are linked. But to "believe" also links with to be "born of God" which links the Christocentric and theocentric lines of salvation. Even in verses 5:11f the "eternal life" theme is introduced. But the theme of faith seems to serve as the unifying theme for this section. Of the nine occurrences of the verb pis t euein in 1 John, five are in these few verses.
} 
various passages or references in the Epistles that relate to one another are combined. The possible constructed circumstances and false teachings of the deceivers that might have influenced the theological doctrine and ethical behaviour of the community, leading to the schism that is reported, determine the structure and content of the soteriology. Only the basic aspects of soteriology are taught by the elder. These basic aspects are presented from theocentric and christocentric perspectives that are closely interwoven with different themes. If one looks at the content, the theological perspective appears to dominate, but it is complemented by the Christocentric perspective.

The soteriology is presented with a familial orientation from the perspective of the household of God the Father. The paternalistic Old Testamentic image of a household is reflected here, with the Father determining the way of conduct. The elder refers to three of God's characteristics (0) qe0," f w" es t in (1:5), [0 qeo," ] dikai ov eś t in (2:29) and 0] qe 0," ag g aph es t i (4:8)), according to which God's children have to direct their lives once "they have been born into the family of God", where they receive and experience "eternal life."

\section{Works consulted}

Achtemeier, P J, Green, J B \& Thompson, M M 2001. Introducing the New Testament (Its literature and theology). Grand Rapids, MI: Eerdmans.

Argyle, A W 1953. 1 John 3:4f. ExpTim 65, 62-63.

Baylis, C P 1992. The meaning of walking "in the darkness" (1 Jn 1:6). BSac 149, 214-222.

Brown, R E 1982. The epistles of John. New York: Doubleday. (AB.)

Brown, R E 1997. New York: An introduction to the New Testament. London: Doubleday.

Bultmann, R. 1978. The Johannine epistles, tr by R P O'Hara. Philadelphia, PA: Fortress Press.

Coetzee, J C 1993. The letters of John in The Gospel of John; Hebrews to Revelation: introduction and theology. Guide to the New Testament VI, ed by A B Du Toit. Pretoria: NG Kerk-Uitgewers.

Culpepper, A 1998. The gospel and letters of John. Nashville, TN: Abingdon Press.

Danker, F W (ed) 2000. Greek English Lexicon of the New Testament and other Early ChristianLiterature. $3^{\text {rd }}$ Edition BDAG. Chicago, IL: University of Chicago Press.

Davids, P H 1997. Faith and works (1-3 Jn), in Dictionary of the Later New Testament \& its Developments, ed by R P Martin \& P H Davids. Illinois, IL: Intervarsity Press.

De Jonge, M 1978. De Brieven van Johannes. Nijkerk: G F Callenbach.

Derickson G W 1993. What is the Message of 1 John?. BSac 150, 89-105. 
Dodd, C H 1946. The Johannine Epistles. MNTC. London: Hodder and Stoughton. Dunn, J D G 1989. Christology in the making. London: SCM Press.

Du Plessis, P J 1978. Die briewe van Johannes. Kaapstad: NG Kerk-Uitgewers.

Edwards, R B 2000. The Johannine epistles, in The Johannine literature, ed by B Lindars, R B Edwards \& J M Court. Sheffield: Academic Press.

Feuillet, A. 1973. The structure of First John (Comparison with the fourth gospel. The pattern of Christian life). BTB 3, 194-216.

Filson, F. V 1969. First John: purpose and message. Int 23, 259-276.

Grayston, K 1984. The Johannine epistles. Grand Rapids, MI: Eerdmans. (NCB.)

Greijdanus, S.1964. I, II, III Johannes. Korte Verklaring. Kampen: Kok.

Haas, C, De Jonge, M \& Swellengrebel, J L 1972. A translater's handbook on the letters of John. London: United Bible Societies.

Hengel, M. 1989. The Johannine question. Philadelphia, PA: Trinity Press International.

Hiebert, D E 1988. An exposition of 1 John 1:1-4. BSac 145, 197-210.

Hiebert, D E 1989a. An exposition of 1 John 2:18-28. BSac 146, 76-93.

Hiebert, D E 1989b. An exposition of 1 John 4:1-6. BSac 146, 420-436.

Hiebert, D E 1990. An exposition of 1 John 5:13-21. BSac 147, 309-328.

Hills, J V 1998. "Sin is lawlessness" (1 Jn 3:4) (Social definition in the Johannine community) in Common life in the early church: Essays honoring Greydon $F$ Snyder, ed by J V Hills. Harrisburg, PA: Trinity Press International.

Kenney, G C 2000a. The relation of Christology to ehics in the first epistle of John. New York, NY: University Press of America.

Kenney, G C 2000b. Leadership in John: An analysis of the situation and strategy of the gospel and the epistles of John. New York: University Press of America.

Kim, S H 1998. Interaction between koinonia and zoe in 1 John, a relational reading. DD-dissertation, University of Stellenbosch.

Klauck, H-J 1991. Der Erste Johannesbrief (EKK). Zürich: Benziger Verlag.

Kümmel, W G 1975. Introduction to the New Testament. London: SCM.

Ladd, G E 1998. A theology of the New Testament. Grand Rapids, MI:Eerdmans.

Lieu, J 1986. The second and third epistles of John. Edinburgh: T \& T Clark.

Lieu, J 1997 (1991). The theology of the Johannine epistles. New Testament theology. Cambridge: University Press.

Louw, J P \& Nida, E A 1988. Greek-English Lexicon of the New Testament based on Semantic Domains, vol 1. New York: United Bible Societies.

Malatesta, E 1978. Interiority and covenant. Rome: Biblical Institute Press.

Lohse, E 1976. The New Testament environment. London: SCM Press Ltd.

Longacre, R 1992. Towards an exegesis of 1 John based on the discourse analysis of the Greek text, in Linguistics and New Testament Interpretation (Essays on Discourse Analysis), ed by D A Black. Nashville,TN: Broadman Press.

Perkins, $P$ 1983. Koinonia in 1 John 1:3-7: The social context of division in the Johannine letters. CBQ 45, 631-641.

Porter, S E 1997. Sin, wickedness, in Dictionary of the later New Testament \& its developments, ed by R P Martin \& P H Davids. Illinois, IL: Intervarsity Press.

Scholer, D M 1975. Sins within and sins without: An interpretation of 1 John 5:16-17, in Hawthorne, G F (ed), Current issues in Biblical and patristic interpretation.

Grand Rapids, MI: Eerdmans.

Scholer, D M 1990. 1 John 4:7-21. RevEx 87, 309-314. 
Strecker, G 1986. Die Anfänge der johanneischen Schule. NTS 32, 31-47.

Strecker, G 1996. The Johanneine letters. Minneapolis, MN: Fortress Press.

Schnackenburg, R 1953. Die Johannesbriefe. Freiburg: Verlag Herder. (HTKNT.)

Schweizer, E 2000. An exegetical analysis of 1 John 1:7, in Alston, W M (ed),

Theology in the service of the church. Grand Rapids, MI: Eerdmans.

Smalley, S S 1984. 1, 2, 3 John. Dallas, TX: Word Books. (WBC 51.)

Thomas, J C 1998. The literary structure of 1 John. NT 40, 369-381.

Thompson, M M 2001. The God of the gospel of John. Grand Rapids, MI: Eerdmans.

Van der Watt, J G 1999. My reading of 1 John in Africa, in Kitzberger, I R (ed), The personal voice in biblical interpretation. London: Routledge.

Vitrano, S P 1987. The doctrine of sin in 1 John. AUSS 25, 123-131.

Von Wahlde, U C 1990. The Johannine commandments: 1 John and the struggle for the Johannine tradition. New York: Paulist Press.

Ward, T 1995. Sin "Not unto death" and "Unto death" in 1 John 5:16. Vine Books 109 (3), 226-237.

Westcott, B F 1982 (1883). The epistles of St John. Johannine studies since Westcott's day by F F Bruce. Grand Rapids, MI: Eerdmans. 